\title{
Carbon and water vapor balance in a subtropical pine plantation
}

\author{
Gabriela Posse ${ }^{(1)}$, Nuria \\ Lewczuk $^{(1-2)}$, Klaus Richter ${ }^{(1)}$, \\ Piedad Cristiano ${ }^{(2-3)}$
}

\begin{abstract}
Afforestation has been proposed as an effective tool for protecting primary and/or secondary forests and for mitigating atmospheric $\mathrm{CO}_{2}$. However, the dynamics of primary productivity differs between plantations and natural forests. The objective of this work was to evaluate the potential for carbon storage of a commercial pine plantation by determining its carbon balance. Measurements started when trees were aged 6 and ended when they were older than 8 years. We measured $\mathrm{CO}_{2}$ and water vapor concentrations using the Eddy covariance method. Gross primary productivity in 2010 and 2011 was $4290 \pm 473 \mathrm{~g} \mathrm{C} \mathrm{m}^{-2}$ and $4015 \pm 485 \mathrm{~g} \mathrm{C} \mathrm{m}^{-2}$, respectively. Ecosystem respiration ranged between 7 and $20 \mathrm{~g} \mathrm{C} \mathrm{m}^{-2} \mathrm{~d}^{-1}$, reaching peaks in all Februaries. Of the 30 months monitored, the plantation acted as carbon source for 21 months and as carbon sink for 6 months, while values close to neutrality were obtained during 3 months. The positive balance representing $\mathrm{CO}_{2}$ loss by the system was most likely due to the cut branches left on the ground following pruning activities. The plantation was subjected to pruning in January and September 2008 and to sanitary pruning in October 2010. In all cases, cut branches were not removed but remained on the ground. Residue management seems to have a very important impact on carbon balance.
\end{abstract}

Keywords: Afforestation, Carbon Source, Ecosystem Respiration, Pruning, Thinning

able option for mitigating the concentration of greenhouse gases (GHGs) in the atmosphere (Nabuurs et al. 2007, McKinley et al. 2011). Afforestation has been proposed as an effective tool for protecting primary and/or secondary forests and for mitigating atmospheric $\mathrm{CO}_{2}$ levels (Shvidenko et al. 1997, Peichl et al. 2010, Korkanç 2014).

The dynamics of primary productivity in plantations differs from that of native forests, as it depends on the age of the stands, the species planted, soil type, climate and management practices (Paul et al. 2002), while that of native forests depends directly on the age of the trees (Noormets et al. 2007). Plantation stands are capable of producing high biomass yields, but they are exposed to continuous disturbances (e.g., field preparation, fertilization, weed control, thinning and har-
(1) INTA - Instituto de Clima y Agua, N. Repetto y De Los Reseros s/n, 1686 Hurlingham, Provincia de Buenos Aires (Argentina); (2) CONICET, Sarmiento 440, Buenos Aires (Argentina); (3) Departamento de Ecología, Genética y Evolución, Instituto IEGEBA (CONICET-UBA), Facultad de Ciencias Exactas y Naturales, Universidad de Buenos Aires (Argentina)

@ Gabriela Posse (posse.gabriela@gmail.com)

Received: Aug 18, 2015 - Accepted: Jan 28, 2016

Citation: Posse G, Lewczuk N, Richter K, Cristiano P (2016). Carbon and water vapor balance in a subtropical pine plantation. iForest 9: 736-742. - doi: 10.3832/ifor1815-009 [online 201605-25]

Communicated by: Tamir Klein vest) which may possibly affect $\mathrm{CO}_{2}$ uptake. Only a few studies conducted in forest systems have included large woody debris such as branches in the analysis of carbon flux because of their low decomposition rate (Chambers et al. 2000). Overall, commercial plantations have been less studied than natural forests. Noormets et al. (2012) reported high values of gross productivity, and high values of soil and litter respiration in a 25 years-old pine plantation. Paul et al. (2003) found that carbon losses occur within the first 10 years after the establishment of the plantation, while 30 years are required to restore the initial levels. The impact of afforestation on the global carbon budget has become increasingly important due to the expansion of plantation areas. McKinley et al. (2011) estimated that plantations are responsible for $50 \%$ of carbon uptake by forests of USA.

The estimation of carbon balance in plantations is a challenge because of the slowness of soil cycling processes, the spatial heterogeneity of soils and the low rate of tree growth. The eddy covariance technique allows direct estimation of the exchange of matter and energy between an ecosystem and the atmosphere (Aubinet et al. 2000, Baldocchi 2003). It is used to measure net ecosystem $\mathrm{CO}_{2}$ exchange (NEE), even for short periods of time, providing information on entire ecosystems over surface areas of the order of hundreds of square meters (Schmid 1994). Moreover, this is a highly robust method because fluxes are obtained almost continuously on timescales ranging from half 
hours to multiple years. Globally, over 500 eddy covariance flux towers are currently operating (http://www.fluxnet.ornl.gov/) Most of these are located in the United States and Europe, while countries of the Southern Hemisphere are poorly represented. Furthermore, the forests sites included in the Fluxnet network often correspond to native forests undisturbed or undergoing restoration.

The present study reports eddy covariance measurements carried out during the first rotation of a commercial pine plantation. Measurements started when trees were 6 years old and lasted for 2.5 years. The plantation was subjected to pruning in January and September 2008, and to sanitary pruning in October 2010. In all these occasions, cut branches were not removed from the ground. Our main objective was to determine the net ecosystem $\mathrm{CO}_{2}$ and water vapor exchange to assess the potential of the pine plantation for carbon storage, in the context of residue practices.

\section{Material and methods}

\section{Study area}

The study was conducted in a commercial Pinus taeda plantation, near the locality of Virasoro, Corrientes province, Argentina ( $28^{\circ} 14^{\prime} 22.2^{\prime \prime} \mathrm{S}, 56^{\circ} 11^{\prime} 19.11^{\prime \prime} \mathrm{W}$ ), between December 2009 and May 2012. The stands were located on a gentle hillock at elevation $127 \mathrm{~m}$ a.s.l. The region has a subtropical climate without a dry season. Mean annual rainfall is $1800 \mathrm{~mm}$, and mean temperature is $21.1{ }^{\circ} \mathrm{C}$, with mean maximum and minimum temperatures of $26.5^{\circ} \mathrm{C}$ and $15.7{ }^{\circ} \mathrm{C}$, respectively (historical data for the period 1980-2010, National Weather Service). Mean air humidity is $72 \%$. The soils belong to the Ultisols order (Kandihumult), with clayish texture, good drainage, and a depth of about $150 \mathrm{~cm}$ (INTA Soil Map at a 1:500,000 scale). The plantation forest was set up in 2003, replacing natural grasslands. It was subjected to pruning in January and September 2008 and to sanitary pruning in October 2010 due to infestation by wood wasp Sirex noctilio, a pest of pine trees. On these occasions, cut branches were left on the forest floor. Measure- ments started when trees were 6 years old and $12 \mathrm{~m}$ in height. The tower equipped with instruments was surrounded by at least $700 \mathrm{~m}$ of homogeneous forest in all directions.

\section{Instruments}

Instruments were installed on a 32-m fire surveillance tower at $18 \mathrm{~m}$ above the ground and at $6 \mathrm{~m}$ above the canopy. The tower is property of Forestal Bosques del Plata S.A. (http://www.bosquesdelplata. com.ar). We used a 3-D sonic anemometer (CSAT ${ }^{\oplus}$, Campbell Scientific, Logan, Utah, USA) for measuring wind speed in the three directions and sonic temperature, and a gas analyzer (LI-7500 ${ }^{\circledast}$, LI-COR, Lincoln, Nebraska, USA) for measuring the absorption of infrared radiation by gases ( $\mathrm{CO}_{2}$ and $\mathrm{H}_{2} \mathrm{O}$ vapor).

Data recorded were stored with a data acquisition system (CR3000 Micrologger ${ }^{\circledR}$, Campbell Scientific, Logan, Utah, USA). The anemometer and the analyzer were placed $20 \mathrm{~cm}$ apart. Net radiation was measured using a NR-Lite ${ }^{\circledR}$ net radiometer (Campbell Scientific, Logan, Utah, USA), and photosynthetically active radiation (PAR) with a GaAsP ${ }^{\circledast}$ photodiode (cavadevices.com, Buenos Aires, Argentina). Missing in situ data due to technical problems for short-term periods were obtained from the Down-welling Surface Shortwave Flux (DSSF) product, which is generated on the basis of satellite data (http://landsaf.me teo.pt/).

\section{Raw data processing and correction procedures}

Raw data from the sonic anemometer and the gas analyzer (three wind velocity components, sonic temperature and concentrations of $\mathrm{CO}_{2}$ and water vapor) were sampled at $20 \mathrm{~Hz}$. For each variable, 36,000 data were averaged over 30-min time periods and then processed to calculate $\mathrm{CO}_{2}$ flux $\left(\mathrm{FCO}_{2}\right.$, in $\left.\mathrm{kg} \mathrm{m}^{-2} \mathrm{~s}^{-1}\right)$. The calculation of $\mathrm{CO}_{2}$ fluxes is based on an equation derived by Webb et al. (1980 - eqn. 1):

$$
\begin{aligned}
& F_{\mathrm{CO} 2}=\overline{w^{\prime} \rho_{\mathrm{CO} 2}^{\prime}}+ \\
& {\left[\frac{m_{d}}{m_{v}} \cdot \frac{\overline{w^{\prime} \rho^{\prime}}}{\overline{\rho_{d}}}+\left(1+\frac{m_{d}}{m_{v}} \cdot \frac{\overline{\rho_{v}}}{\bar{\rho}_{d}}\right) \cdot \frac{\overline{w^{\prime} T^{\prime}}}{\bar{T}}\right] \cdot \overline{\rho_{\mathrm{CO} 2}}}
\end{aligned}
$$

where $T$ is air temperature (in $\mathrm{K}$ ), $m_{\mathrm{d}} / m_{\mathrm{v}}=$ 1.6077 is the ratio of the molar mass of dry air $\left(m_{\mathrm{d}}\right)$ and the molar mass of water vapor $\left(m_{\mathrm{v}}\right)$, and $\rho_{\mathrm{CO}_{2}}, \rho_{\mathrm{v}}$ and $\rho_{\mathrm{d}}$ are the densities of $\mathrm{CO}_{2}$, water vapor and dry air (in $\mathrm{kg} \mathrm{m}^{-3}$ ), respectively. The equation assumes stationary and horizontally homogeneous conditions.

We applied the corrections indicated in Tab. 1, i.e., synchronization between the sonic anemometer and gas analyzer, tilt correction to the vertical velocity measured by the sonic anemometer, conversion of sonic temperature data into air temperature data when needed, and covariance correction for the inclusion of all the frequencies of $\mathrm{CO}_{2}$ turbulent transfer. Raw data were processed and fluxes were calculated using the free software EddyPro (LiCor Biosciences, Lincoln, Nebraska, USA). Outlier cleaning and removal of data below the turbulence threshold were carried out with the free software $R$ (http://www.r-project.org) and Visual Basic for Application (VBA) within a Microsoft Excel $^{\oplus}$ platform. The procedure to calculate NEE, GPP and respiration using the values measured is depicted in Fig. 1.

We used the model of Hsieh et al. (2000) to estimate the actual footprint of the measured fluxes. By applying this model, we calculated the distance from the sensors at which footprint contribution is maximum (Hmax) and the surface area including $80 \%$ of the footprint value to confirm whether the measured fluxes corresponded to the study area. Ecosystem evapotranspiration was calculated from the latent heat flux $\lambda E$ (in $\mathrm{W} \mathrm{m}^{-2}$ ), following Foken (2008 - eqn. 2):

$$
\lambda E=\lambda \cdot\left(1+\frac{m_{d}}{m_{v}} \cdot \frac{\overline{\rho_{v}}}{\overline{\rho_{d}}}\right) \cdot\left(\overline{w^{\prime} \rho^{\prime}{ }_{v}}+\overline{\rho_{v}} \cdot \frac{\overline{w^{\prime} T^{\prime}}}{\bar{T}}\right)
$$

where $\lambda\left(\approx 2.454 \mathrm{MJ} \mathrm{kg}^{-1}\right)$ is the latent vaporization heat, which depends slightly on temperature, and $E$ is the water vapor flux (in $\mathrm{kg} \mathrm{m} \mathrm{m}^{-2} \mathrm{~s}^{-1}$ ) corresponding to the evapotranspiration rate, which can be expressed as (eqn. 3):

\begin{tabular}{|c|c|c|}
\hline Problem & Correction method & Bibliographic sources \\
\hline $\begin{array}{l}\text { Time lag between sonic anemometer } \\
\text { and gas analyzer measurement }\end{array}$ & $\begin{array}{l}\text { Maximization of the covariances between the vertical } \\
\text { wind velocity and } \mathrm{CO}_{2} \text { and water vapor concentrations }\end{array}$ & Aubinet et al. (2012) \\
\hline $\begin{array}{l}\text { Sonic anemometer is slightly tilted, } \\
\text { requiring correction of wind velocity } \\
\text { measurements }\end{array}$ & $\begin{array}{l}\text { Rotation of the coordinate system and re-calculation of } \\
\text { horizontal and vertical components of wind velocity }\end{array}$ & $\begin{array}{l}\text { Aubinet et al. (2000), Wilczak et } \\
\text { al. (2001) }\end{array}$ \\
\hline $\begin{array}{l}\text { Measurement of sonic temperature } \\
\text {-instead of air temperature- to calculate } \\
\text { the } \mathrm{CO}_{2} \text { flux with the equation of Webb et } \\
\text { al. }(1980)\end{array}$ & $\begin{array}{l}\text { Estimation of air temperature and of covariances } \\
\text { containing air temperature based on measurements of } \\
\text { sonic temperature and air humidity }\end{array}$ & $\begin{array}{l}\text { Schotanus et al. (1983), Liu et al. } \\
\text { (2001) }\end{array}$ \\
\hline $\begin{array}{l}\text { Missing values of turbulence due to } \\
\text { instrumental limitations point out the } \\
\text { need of covariance correction }\end{array}$ & $\begin{array}{l}\text { Spectral correction of covariances considering } \\
\text { turbulence frequencies that were not captured by the } \\
\text { measurement system }\end{array}$ & $\begin{array}{l}\text { Kaimal et al. (1972), Moore (1986), } \\
\text { Moncrieff et al. (1997), Massman } \\
\text { (2000), Massman \& Clement (2004) }\end{array}$ \\
\hline
\end{tabular}

$$
E T=\frac{1000 \cdot \Delta t}{\rho_{H 2 O}} \cdot \sum_{i=1}^{48} E_{i}=1756 \cdot \sum_{i=1}^{48} E_{i}
$$

Tab. 1 - Corrections applied to raw data recorded by the instruments of the measurement system. 
where $E T$ is the evapotranspiration (in $\mathrm{mm}$ $\left.\mathrm{H}_{2} \mathrm{O} \mathrm{d}^{-1}\right), \rho_{\mathrm{H} 2 \mathrm{O}}$ is the water density $(1025 \mathrm{~kg}$ $\left.\mathrm{m}^{-3}\right)$ and $E_{\mathrm{i}}$ is the water vapor flux measured for each of the 48 half-hours in a day.

Removal of $\mathrm{CO}_{2}$ fluxes under low friction velocity conditions and data gap filling

The Eddy covariance technique requires turbulent conditions. The lack of turbulence is associated with low friction velocities $\left(u^{*}\right)$. The method described by Reichstein et al. (2005) was applied to determine the threshold value, using a moving window ( \pm 14 days). During periods when friction velocity $\left(u^{*}\right)$ was below a threshold value, $\mathrm{CO}_{2}$ fluxes were removed from the data set. Data gaps were due to technical problems involving sensor calibration, maintenance of the experimental system, power failure and data acquisition failure. Gaps were filled according to the methodology proposed by Falge et al. (2001) and Reichstein et al. (2005), and subsequently recommended by Moffat et al. (2007). The half-hourly Net Ecosystem Exchange was calculated as the sum of $\mathrm{CO}_{2}$ fluxes and expressed on a daily, monthly or annual basis.

The uncertainty in estimates was calculated by applying the method of Hollinger $\&$ Richardson (2005), which is based on the pairwise comparison between $\mathrm{CO}_{2}$ flux values measured within one day under similar meteorological conditions of solar radiation, temperature and wind speed. The gap-filling error was also estimated by first removing each $\mathrm{CO}_{2}$ flux record one at a time from the data set, applying the gapfilling methodology and then comparing the measured and calculated values. This procedure was repeated for each $\mathrm{CO}_{2}$ flux measured, thus obtaining a set of differences between the measured and calculated values. A histogram of these differences can be used to derive the standard deviation of the underlying distribution, in the same way as for the analysis of the random measurement error.

\section{Ecosystem Respiration $\left(R_{\text {eco }}\right)$ and Gross} Primary Production (GPP)

We used an Arrhenius-like model to describe the dependence of respiration on temperature (Lloyd \& Taylor 1994). Ecosystem Respiration was calculated as follows (eqn.4):

$$
R=R_{r e f} \cdot e^{E_{0}\left(\frac{1}{T_{r e f}-T_{0}}-\frac{1}{T-T_{0}}\right)}
$$

where $R_{\text {eco }}$ is the Ecosystem Respiration (in $\mathrm{mg} \mathrm{CO}_{2} \mathrm{~m}^{-2} \mathrm{~s}^{-1}$ ), $T$ is the temperature (in ${ }^{\circ} \mathrm{C}$ ), $R_{\text {ref }}$ is for $T=T_{\text {ref }}, E_{0}$ is a parameter related to activation energy (in ${ }^{\circ} \mathrm{C}$ ), $T_{\text {ref }}$ is the reference temperature $\left(=10^{\circ} \mathrm{C}\right)$, and $T_{0}$ is a parameter set at $-46.02{ }^{\circ} \mathrm{C}$.

The methodology described by Reichstein et al. (2005) was used to determine the values of $R_{\text {ref }}$ and $E_{0}$, based on the regression analysis of fluxes measured dur-

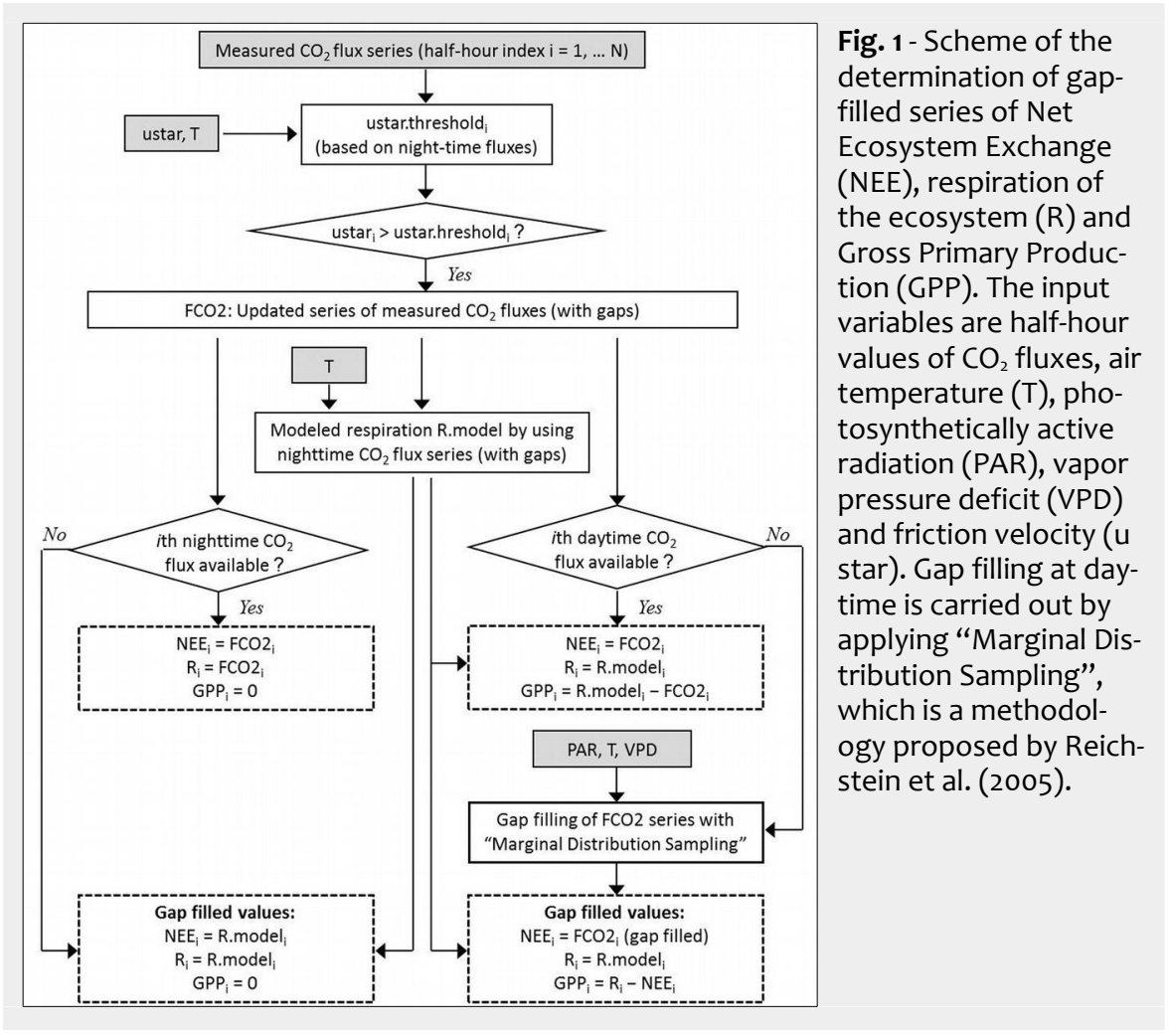

ing nighttime. A single value was assigned Results

to $E_{\mathrm{o}}$ for the entire study period, while $R_{\text {ref }}$ was calculated within a 7-night window. In addition, Reichstein et al. (2005) provided an equation for estimating the error associated with the calculated Ecosystem Respiration (eqn. 5):

$$
\Delta R=R\left[\frac{\Delta R_{r e f}}{R_{r e f}}+\Delta E_{0} \cdot \frac{T-T_{r e f}}{\left(T_{r e f}-T_{o}\right) \cdot\left(T-T_{0}\right)}\right]
$$

Mean air temperature during the study period ranged between $15.2{ }^{\circ} \mathrm{C}$ (June 2011) and $28.3^{\circ} \mathrm{C}$ (January 2011). Solar radiation ranged between $32 \mathrm{MJ} \mathrm{m}^{-2}$ in summer and $13 \mathrm{MJ} \mathrm{m}^{-2}$ in winter. Accumulated rainfall for 2010 and 2011 was $1573 \mathrm{~mm}$ and 1516 $\mathrm{mm}$, respectively, these values being similar to each other but lower than the climatological mean (Fig. 2).

At the beginning of the study period We can now calculate the Gross Primary (summer 2009/2010) we obtained the patProduction (GPP) as follows (eqn. 6):

$$
G P P=-N E E+R
$$

A conservative estimate of the error in Gross Primary Production $(\triangle \mathrm{GPP})$ is given by (eqn. 7):

$\triangle G P P=\Delta N E E+\Delta R$ tern of $\mathrm{CO}_{2}$ flux expected for a green ecosystem. The maximum values of instantaneous $\mathrm{CO}_{2}$ flux to the ecosystem were around $-1.8 \mathrm{mg} \mathrm{CO}_{2} \mathrm{~m}^{-2} \mathrm{~s}^{-1}$ and nighttime respiration reached a peak of $1 \mathrm{mg} \mathrm{CO}_{2} \mathrm{~m}^{-2}$ $\mathrm{s}^{-1}$ (Fig. 3). The minimum and maximum values of Ecosystem Evapotranspiration (ET) were obtained in June 2010 (mean daily ET of $1.4 \mathrm{~mm}$ ) and January 2010 (mean daily

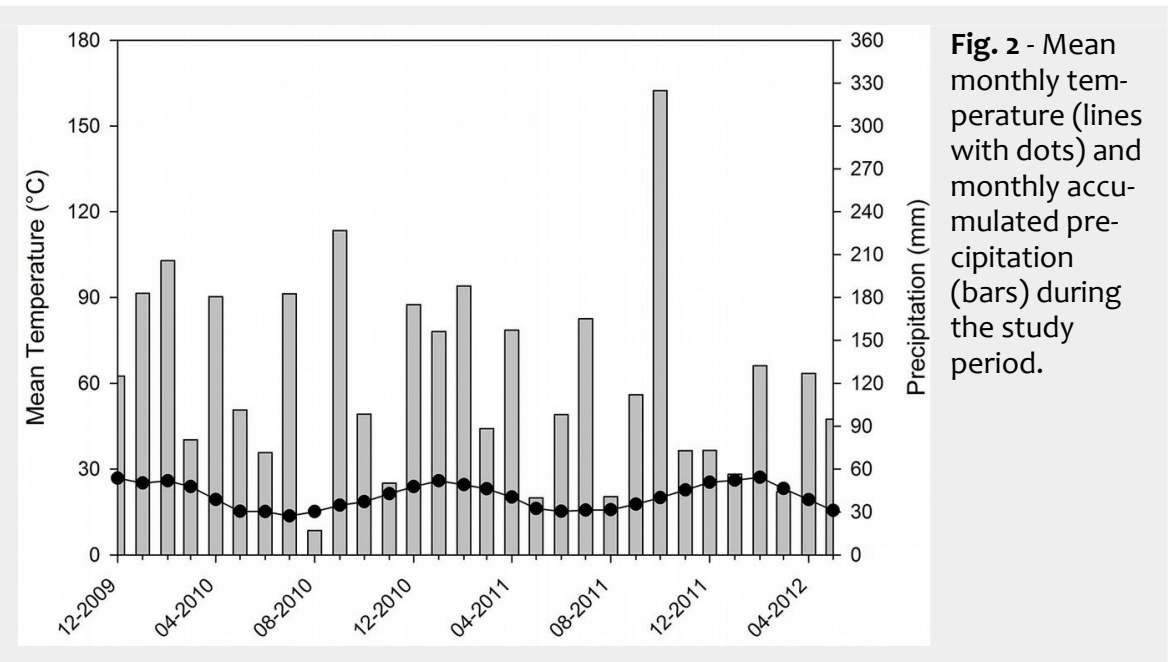



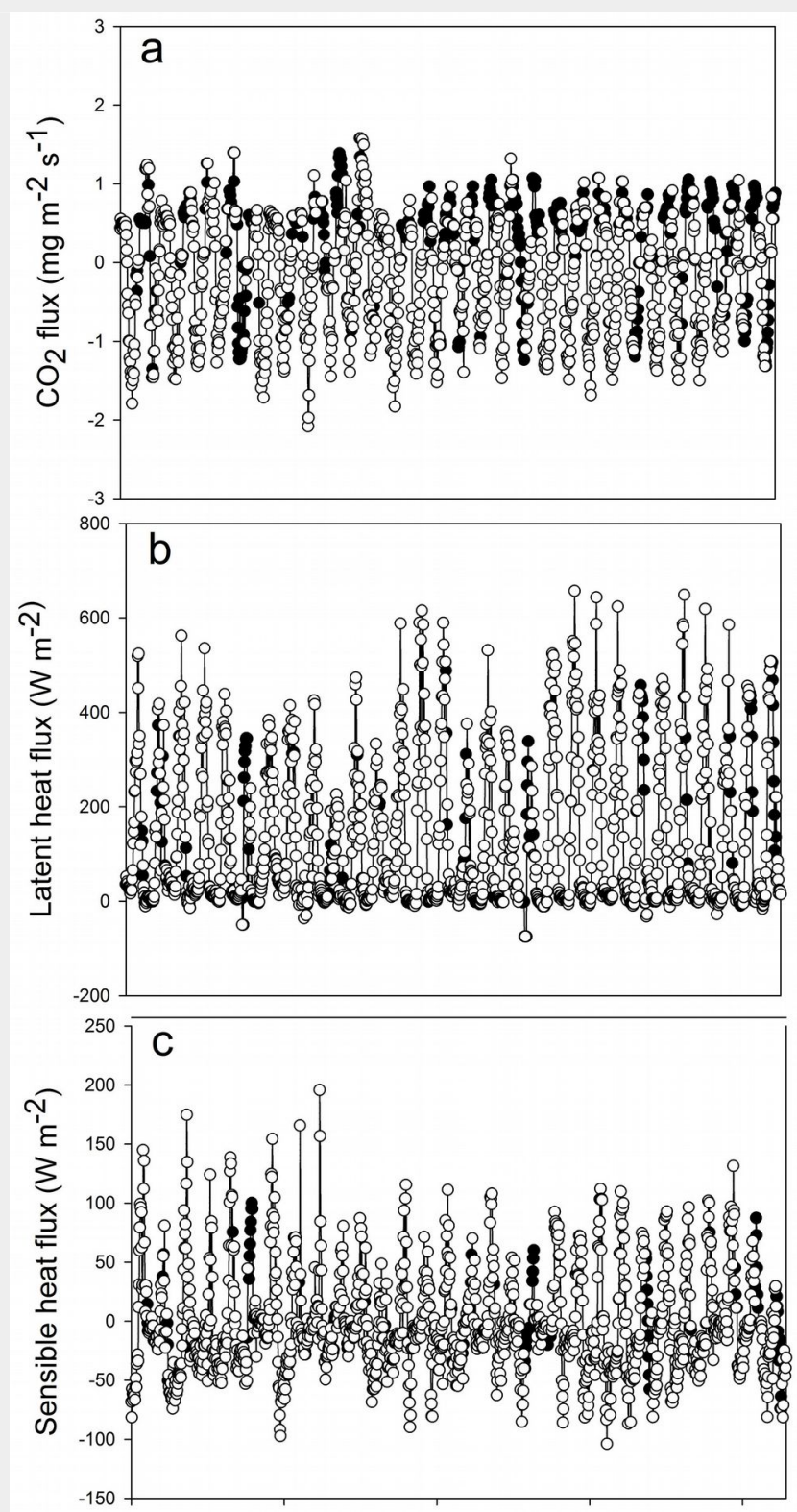

01/01/2010 08/01/2010 15/01/2010 22/01/2010 29/01/2010

Fig. 3 - Extracts of flux series (January 2010): (a) carbon dioxide, (b) latent heat and (c) sensible heat. The white symbols represent measured fluxes, the black symbols represent gapfilled values.

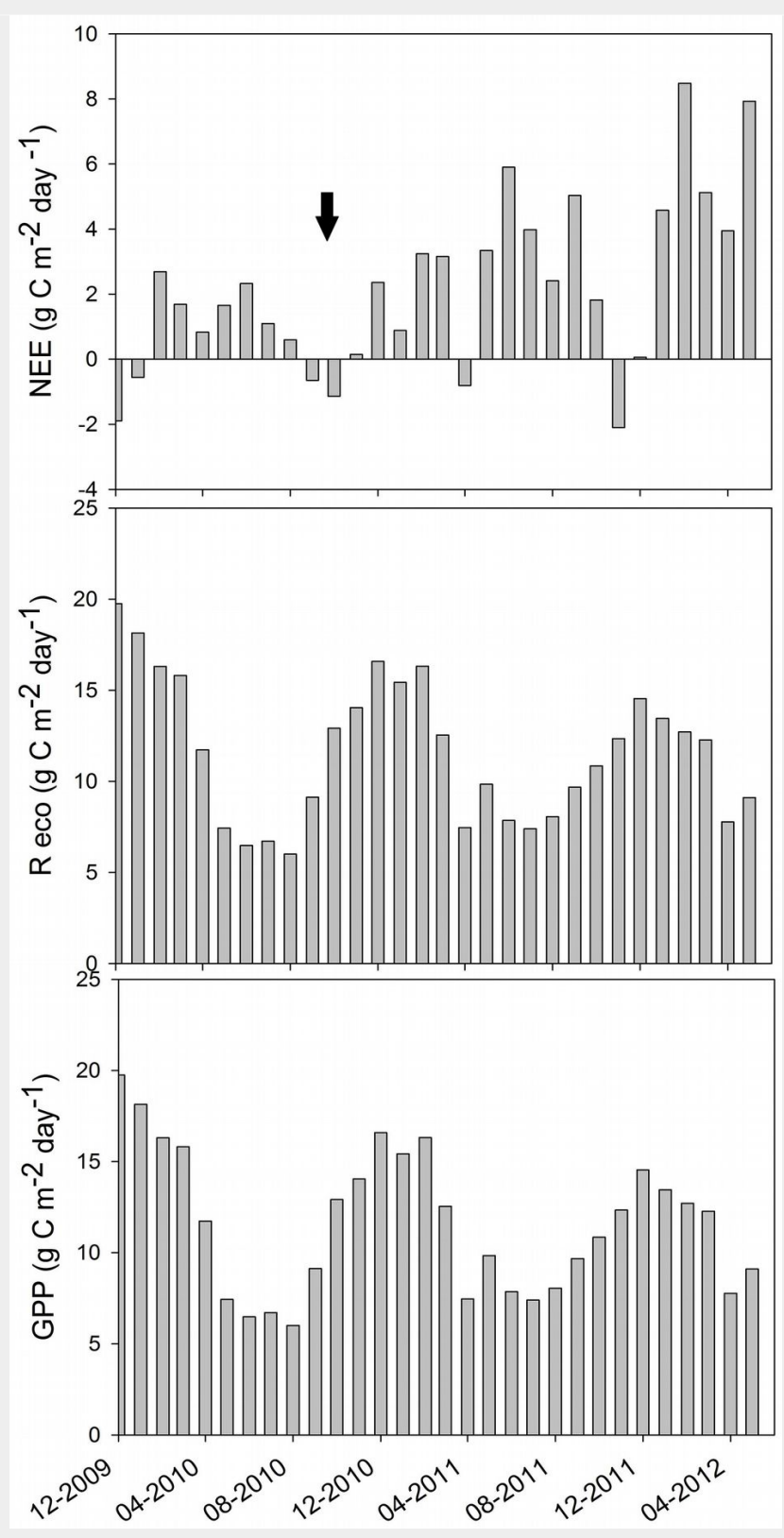

Fig. 5 - Daily mean of the (a) Net Ecosystem Exchange (NEE), (b) respiration of the ecosystem $\left(R_{\text {eсо }}\right)$ and (c) Gross Primary Production (GPP) of the ecosystem during the measurement period, between December 2009 and May 2012. The moving average of the GPP is also shown, highlighting the seasonal dependence of the pine plantation to carbon storage due to tree growth. Dark arrow points out the sanitary pruning date.

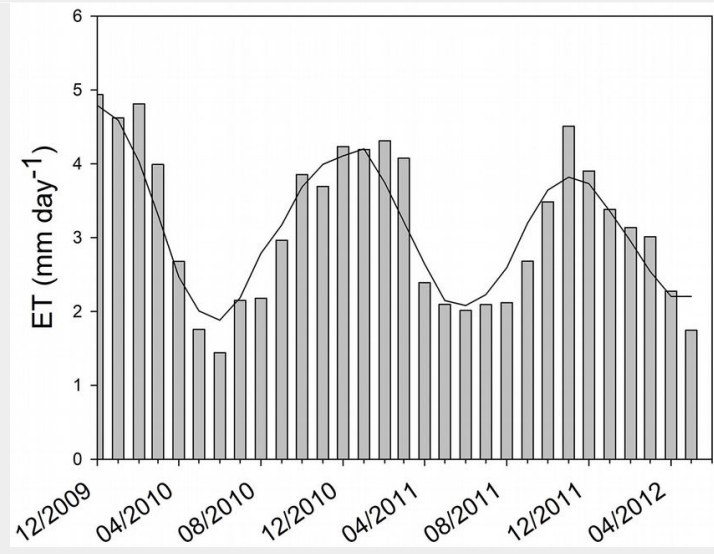

Fig. 4 - Daily mean of evapotranspiration $(E T)$ in $\mathrm{mm} \mathrm{H}_{2} \mathrm{O}$ $\mathrm{d}^{-1}$. The evapotranspiration is calculated by using the latent heat flux measured in the pine forest between December 2009 and May 2012. The moving average line highlights the seasonal behavior of the evapotranspiration.
$E T$ of about $5 \mathrm{~mm}$ ), respectively (Fig. 4). Overall, ET was $1161 \mathrm{~mm}$ for 2010 and 1132 $\mathrm{mm}$ for 2011 (from January to December). By comparing ET and rainfall values, it can be seen that there was a positive water balance (water gain) of $412 \mathrm{~mm}$ in 2010 and $384 \mathrm{~mm}$ in 2011.

A maximum daily mean NEE of $-2.1 \mathrm{~g} \mathrm{C} \mathrm{m}^{-2}$ $\mathrm{d}^{-1}$ was recorded in November 2011 and a minimum daily mean NEE of $8.5 \mathrm{~g} \mathrm{C} \mathrm{m}^{-2} \mathrm{~d}^{-1}$ in February 2012 (Fig. 5a). The system had positive values of NEE in most of the months (acting as a carbon source), while it had negative values in December 2009, January, September and October 2010, and April and November 2011 (acting as a car- 
Fig. 6 - Half-hourly frequency (a) of the distance between the flux tower and the footprint maximum and (b) of the distance between the flux tower and the point that represents $80 \%$ of the integrated footprint. The footprint calculations were carried out with the footprint model of Hsieh et al.

(2000).
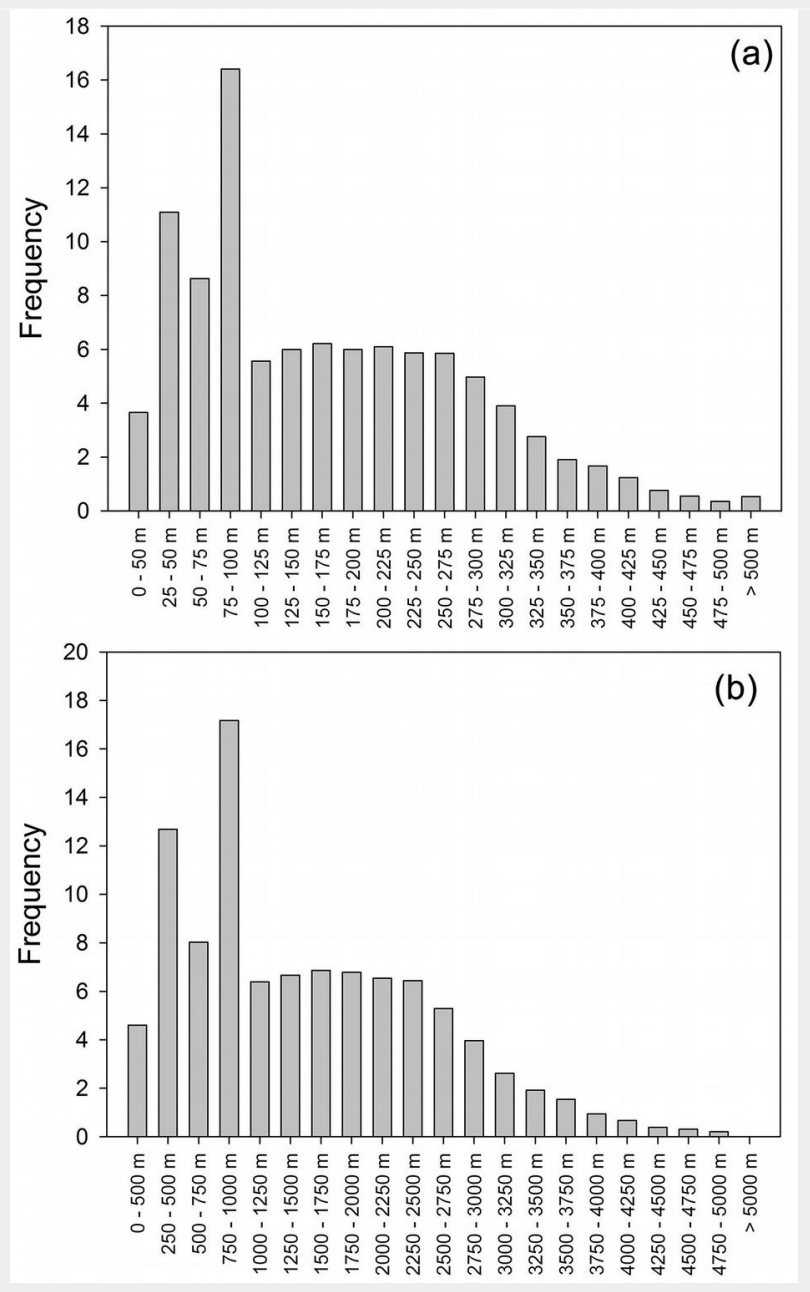

bon sink). Ecosystem respiration was calculated with $E_{0}=(344 \pm 32){ }^{\circ} \mathrm{C}$, which falls within the range reported by previous studies for other locations (Reichstein et al. 2005). Ecosystem respiration ranged between 7 and about $20 \mathrm{~g} \mathrm{C} \mathrm{m}^{-2} \mathrm{~d}^{-1}$, with maximum values in summer, as expected based on its dependence with temperature. In general, peaks were observed in February of both years, with only slight differences among the maximum values for the three summers (Fig. 5b). Likewise, highest and lowest values of daily GPP were obtained for the summer and winter months, respectively (Fig. $5 \mathrm{C}$ ). The maximum GPP was obtained in December 2009, with about $20 \mathrm{~g} \mathrm{C} \mathrm{m}^{-2} \mathrm{~d}^{-1}$, and the minimum GPP was recorded in August 2010, with 6.0 $\mathrm{g} \mathrm{C} \mathrm{m}^{-2} \mathrm{~d}^{-1}$. Maximum GPP decreased from about $20 \mathrm{~g} \mathrm{C} \mathrm{m}^{-2} \mathrm{~d}^{-1}$ in December 2009, to 17 $\mathrm{g} \mathrm{C} \mathrm{m}^{-2} \mathrm{~d}^{-1}$ in December 2010, to $12 \mathrm{~g} \mathrm{C} \mathrm{m}^{-2} \mathrm{~d}^{-1}$ in December 2011. This result is probably due to the growth of the stand, as trees were 6 years old at the beginning of the 2.5-year study period. Mean GPP ( \pm SD) was $4290 \pm 473 \mathrm{~g} \mathrm{C} \mathrm{m}^{-2}$ for 2010 and $4015 \pm$ $485 \mathrm{~g} \mathrm{C} \mathrm{m}^{-2}$ for 2011. Uncertainty analysis showed a random error of $0.31 \mathrm{mg} \mathrm{CO}_{2} \mathrm{~m}^{-2}$ $\mathrm{s}^{-1}$ and the gap-filling error was $0.27 \mathrm{mg} \mathrm{CO}_{2}$ $\mathrm{m}^{-2} \mathrm{~s}^{-1}$, resulting in total errors of about $1 \mathrm{~g}$ $\mathrm{C} \mathrm{m}^{-2} \mathrm{~d}^{-1}$.

The footprint analysis revealed that the point of maximum contribution of the footprint was at a distance of up to $144 \mathrm{~m}$ to the sensors, while $80 \%$ of the footprint value was within an area with a radius of $1294 \mathrm{~m}$ around the sampling point (Fig. 6). These results confirm that the fluxes measured corresponded to the stands under consideration.

\section{Discussion}

The analysis of the GPP dynamics during our 2.5-year study shows maximum values in the summer months, mainly December. The highest instantaneous rates ranged between -2.5 and $-3.0 \mathrm{mg} \mathrm{CO} \mathrm{Cm}^{-2} \mathrm{~s}^{-1}$, these values being similar to those reported for other areas. For example, Goldstein et al. (2000) obtained GPP values ranging between 3.3 and $4.0 \mathrm{mg} \mathrm{CO}_{2} \mathrm{~m}^{-2} \mathrm{~s}^{-1}$ for young ponderosa pine plantations in the Sierra Nevada Mountains, California. On the other hand, Coursolle et al. (2006) reported maximum NEE values of up to -2.0 $\mathrm{mg} \mathrm{CO} \mathrm{m}^{-2} \mathrm{~s}^{-1}$ for conifer stands of different age, while young forest stands had a remarkably lower NEE (about $-0.25 \mathrm{mg}$ de $\left.\mathrm{CO}_{2} \mathrm{~m}^{-2} \mathrm{~s}^{-1}\right)$.

Net carbon gain is expected to occur in a forest, as reported for other forests of the world (Curtis et al. 2002, Marino et al. 2005). Many studies have recorded an increase in $\mathrm{CO}_{2}$ emissions after harvest with- out providing any information on their origin, while others found no effect. Covington (1981) and Yanai et al. (2003) estimated a carbon loss of $20 \%$ following tree harvest. Pruned branches left on the forest floor can be expected to contribute to soil carbon, but only as long as carbon fixation rate exceeds their respiration rate. Often, changes in temperature and humidity due to land work lead to changes in ecosystem respiration rates (Toland \& Zak 1994, Yanai et al. 2003, Hagemann et al. 2010).

However, some studies have also reported positive NEE values but the system acted as a net carbon source. For example, Cai et al. (2011), who studied a hybrid poplar plantation on a former agricultural land in Alberta, Canada, found that the annual carbon balance shifted from a net source of $312 \mathrm{~g} \mathrm{C} \mathrm{m}^{-2}$ in year 1 , to approximately Cneutral in year 5. Law et al. (2001) stated that ecosystem respiration in young stands may be higher than the NPP of the regrowth due to the decomposition of dead biomass from the previous forest generation. They compared net ecosystem production (NEP) between young (14 years old) and old (45/250 years old) pine stands in Oregon and found that the old stands gained carbon at a rate of $28 \mathrm{~g} \mathrm{C} \mathrm{m}^{-2} \mathrm{yr}^{-1}$, while the young stands lost carbon at a rate of $32 \mathrm{~g} \mathrm{C} \mathrm{m}^{-2} \mathrm{yr}^{-1}$. This indicates that the young stands did not yet reach the net sequestration capacity of the old ones. Our study area also experienced a drastic ecosystem alteration because the original ecosystem (natural grassland) was replaced by a plantation in 2003. We detected that the system acted as a carbon sink only during December 2009, January, September and October 2010, and April and November 2011.

It is probably that the high ecosystem respiration rates obtained in the study area resulted from pruning conducted prior to our measurements and from the sanitary pruning made during the course of this study in October 2010, after which a large amount of cut branches accumulated on the ground until they were subjected to decomposition, whose rate is expected to increase with time. It is reasonable to suppose that the remains of branches left on the ground increased the amount of soil carbon available for the ecosystem respiration. Noormets et al. (2012) found that respiration of plant litter lasted for 2 years, while heterotrophic respiration (from root remains) showed an emission peak at 3 and 4 years after harvest. In addition, they stated that part of the "old" soil carbon pool was respired, and that it took 4.5 years for the plantation to act as a carbon sink and 9.5 years to regain the carbon sink capacity after harvest.

Forestry also has a substantial impact on the albedo and the hydrological balance, in terms of evapotranspiration, water infiltration into the soil and water lost by runoff. These factors, which may account for major changes in local climate conditions 
and water availability downstream (Bonan 2008, Nosetto et al. 2012), should be taken into account when planning a major landuse change such as the one considered in our study, i.e., from grassland to plantation. In the study area, the dynamics of the river basin appears to be unaffected by forest stands because water is not a limiting resource.

\section{Conclusions}

In our study area, the estimated respiration rates resulted from the respiration of trees, soil microorganisms and soil carbon. The replacement of the original grassland by a pine plantation (e.g., removal of the original vegetation, land preparation) led to changes with long-term consequences. A large amount of cut branches resulting from pruning activities were accumulated on the ground and subjected to decomposition. As a consequence, the studied forest had high ecosystem respiration rates, up to $20 \mathrm{~g} \mathrm{C} \mathrm{m}^{-2} \mathrm{~d}^{-1}$ in summer. The decrease in GPP with time and the maintenance of ecosystem respiration rates cause NEE to increase with time, with positive values indicating carbon loss. Thus, the system acted as a carbon source in most of the months, in contrast to that expected for a forest system.

\section{Acknowledgements}

Thanks are due to Forestal Bosques del Plata S.A. (FBP) for allowing field measurements in the plantation (Technical Cooperation Agreement INTA/FBP No. 20020); to Cesar Niklas, German Becerro and Darío Britez from FBP for their assistance with the logistics; to Mr. Fabián, the operator of the fire surveillance tower; to Martin Bellomo and Jorgelina Corin for their help in sensor setting-up and maintenance. Silvia Pietroskovsky improved the English version. NL and PC are PhD fellows of the Consejo Nacional de Investigaciones Cientificas y Ténicas (CONICET), Argentina, and KR was supported by the Center for International Migration (CIM), Frankfurt, Germany. This work was supported by the Instituto Nacional de Tecnología Agropecuaria (INTA), Projects AERN 3632, AERN 239321 and PNNAT 1128023.

\section{References}

Aubinet M, Grelle A, Ibrom A, Rannik Ü Moncrieff J, Foken T, Kowalski AS, Martin PH, Berbigier P, Bernhofer Ch Vlement R, Elbers J, Granier A, Grünwald T, Morgentensern K, Pilegaard K, Rebmann C, Snijders W, Valentini R, Vesala T (2000). Estimates of the annual net carbon and water exchange of forests: the EUROFLUX methodology. Advances in Ecological Research 30: 113-175. - doi: 10.1016/S0065-2504 (08)60018-5

Aubinet M, Vesala T, Papale D (2012). Eddy covariance. A practical guide to measurement and data analysis. Springer, Dordrecht, Heidelberg, London, New York, pp. 438. [online] URL: http://books.google.com/books?id=8azbIJER5Z wC
Baldocchi DD (2003). Assessing the eddy covariance technique for evaluating carbon dioxide exchange rates of ecosystems: past, present and future. Global Change Biology 9: 479-492. doi: 10.1046/j.1365-2486.2003.00629.x

Bonan GB (2008). Forests and climate change: forcings, feedbacks, and the climate benefits of forests. Science 320 (5882): 1444-1449. - doi: 10.1126/science. 1155121

Cai T, Price DT, Orchansky AL, Thomas BR (2011). Carbon, water, and energy exchanges of a hybrid poplar plantation during the first five years following planting. Ecosystems 14 (4): 658-671. - doi: 10.1007/s10021-011-9436-8

Chambers JQ, Higuchi N, Schimel JP, Ferreira LV, Melack JM (2000). Decomposition and carbon cycling of dead trees in tropical forests of the central Amazon. Oecologia 122: 380-388. - doi: 10.1007/s004420050044

Coursolle C, Margolis HA, Barr AG, Black TA, Amiro BD, McCaughey JH, Flanagan LB, Lafleur PM, Roulet NT, Bourque CPA, Arain MA, Wofsy SC, Dunn A, Morgenstern K, Orchansky AL, Bernier PY, Chen JM, Kidston J, Saigusa N, Hedstrom N (2006). Late-summer carbon fluxes from Canadian forests and peatlands along an east-west continental transect. Canadian Journal of Forest Research 36 (3): 783-800. - doi: $10.1139 / \times 05-270$

Covington WW (1981). Changes in forest floor organic matter and nutrient content following clear cutting in northern hardwoods. Ecology 62: 41-48. - doi: 10.2307/1936666

Curtis PS, Hanson PJ, Bolstad P, Barford C, Randolph JC, Schmid HP, Wilson KB (2002). Biometric and eddy-covariance based estimates of ecosystem carbon storage in five eastern North American deciduous forests. Agricultural and Forest Meteorology 113: 3-19. - doi: 10.1016/So1 68-1923(02)00099-0

Falge E, Baldocchi D, Olson R, Anthoni P, Aubinet $M$, Bernhofer $C$, Burba $G$, Ceulemans $G$, Clement R, Dolman H, Granier A, Gross P, Grunwald T, Hollinger D, Jensen NO, Katul G, Keronen $P$, Kowalski A, Lai CT, Law BE, Meyers T, Moncrieff J, Moors E, Munger JW, Pilegaard K, Rannik U, Rebmann C, Suyker A, Tenhunen J, Tu K, Verma S, Vesala T, Wilson K, Wofsy S (2001). Gap filling strategies for long term energy flux data sets. Agricultural and Forest Meteorology 107: 71-77. - doi: 10.1016/S0168-1923(00)00235-5 Foken T (2008). Micrometeorology. Springer, Berlin, Germany, pp. 908. - doi: 10.1007/978-3540-74666-9

Goldstein A, Hultman N, Fracheboud J, Bauer M, Panek J, Xu M, Qi Y, Guenther AB, Baugh WM (2000). Effects of climate variability on the carbon dioxide, water, and sensible heat fluxes above a ponderosa pine plantation in the Sierra Nevada (CA). Agricultural and Forest Meteorology 101: 113-129. - doi: 10.1016/S0168-1923(99) 00168-9

Hagemann U, Moroni MT, Gleibner J, Makeschin F (2010). Disturbance history influences downed woody debris and soil respiration. Forest Ecology and Management 260 (10): 1762-1772. doi: 10.1016/j.foreco.2010.08.018

Hollinger DY, Richardson AD (2005). Uncertainty in eddy covariance measurements and its application to physiological models. Tree Physiology 25: 873-885. - doi: 10.1093/treephys/25.7.873
Hsieh Cl, Katul G, Chi T (2000). An approximate analytical model for footprint estimation of scalar fluxes in thermally stratified atmospheric flows. Advances in Water Resources 23: 765772. - doi: 10.1016/S0309-1708(99)00042-1

IPCC (2014). Climate change 2014: Mitigation of climate change. Contribution of Working Group III to the Fifth Assessment Report of the Intergovernmental Panel on Climate Change (Edenhofer O, Pichs-Madruga R, Sokona Y, Farahani E, Kadner S, Seyboth K, Adler A, Baum I, Brunner S, Eickemeier P, Kriemann B, Savolainen J, Schlömer S, von Stechow C, Zwickel T, Minx JC eds.). Cambridge University Press, Cambridge, United Kingdom and New York, NY, pp. 1435. Kaimal JC, Wyngaard JC, Izumi Y, Cote OR (1972). Spectral characteristics of surface-layer turbulence. Quarterly Journal of The Royal Meteorological Society 98: 563-589. - doi: 10.1002/qj.497 09841707

Korkanç SY (2014). Effects of afforestation on soil organic carbon and other soil properties. Catena 123: 62-69. - doi: 10.1016/j.catena.2014. 07.009

Law BE, Thornton PE, Irvine J, Anthoni PM, Van Tuyl S (2001). Carbon storage and fluxes in ponderosa pine forests at different developmental stages. Global Change Biology 7 (7): 755-777. doi: 10.1046/j.1354-1013.2001.00439.x

Liu H, Peters G, Foken T (2001). New equations for sonic temperature variance and buoyancy heat flux with an omnidirectional sonic anemometer. Boundary-Layer Meteorology 100: 459468. - doi: 10.1023/A:1019207031397

Lloyd J, Taylor JA (1994). On the temperature dependence of soil respiration. Functional Ecology 8: 315-323. - doi: 10.2307/2389824

Marino C, Manca G, Matteucci G, Scarascia Mugnozza G (2005). Climate change in the Mediterranean basin: a case study on carbon cycle in a forest of southern Italy. Forest@ - Rivista di Selvicoltura ed Ecologia Forestale 2 (1): 52-65. [in Italian with English summary] - doi: 10.3832/ eforo259-0020052

Massman WJ (2000). A simple method for estimating frequency response corrections for eddy covariance systems. Agriculture and Forest Meteorology 104: 185-198. - doi: 10.1016/So1 68-1923(00)00164-7

Massman W, Clement R (2004). Uncertainty in eddy covariance flux estimates resulting from spectral attenuation. In: "Handbook of Micrometeorology: A Guide for Surface Flux Measurement and Analysis" (Lee X, Massman WJ, Law E eds). Kluwer, Dordrecht, Netherlands, pp. 67-100. - doi: 10.1007/1-4020-2265-4_4

McKinley SC, Ryan MG, Birdey RA, Giardina CP, Harmon ME, Heath LS, Houghton RA, Jackson RB, Morrison JF, Murray BC, Pataki DE, Skog KE (2011). A synthesis of current knowledge on forest and carbon storage in the United States. Ecological Applications 21 (6): 1902-1924. - doi: 10.1890/10-0697.1

Moffat AM, Papale D, Reichstein M, Hollinger D, Richardson AD, Barr AG, Beckstein C, Braswell $\mathrm{BH}$, Churkina $\mathrm{G}$, Desai AR, Falge E, Gove JH, Heimann $M$, Hui D, Jarvis AJ, Kattge J, Noormets A, Stauch V (2007). Comprehensive comparison of gap-filling techniques for eddy covariance net carbon fluxes. Agricultural and Forest Meteorology 147: 209-232. - doi: 10.1016/ 
j.agrformet.2007.08.011

Moncrieff JB, Massheder JM, De Bruin H, Elbers J, Friborg T, Heusinkveld B, Kabat P, Scott S Sogaard H, Verhoef A (1997). A system to measure surface fluxes of momentum, sensible heat, water vapour and carbon dioxide. Journal of Hydrology 188-189: 589-611. - doi: 10.1016/So 022-1694(96)03194-0

Moore CJ (1986). Frequency response corrections for eddy correlation systems. BoundaryLayer Meteorology 37: 17-35. - doi: 10.1007/BFo 0122754

Nabuurs GJ, Masera O, Andrasko K, BenitezPonce P, Boer R, Dutschke M, Elsiddig E, FordRobertson J, Frumhoff $P$, Karjalainen T, Krankina O, Kurz WA, Matsumoto M, Oyhantcabal W, Ravindranath NH, Sanz Sanchez MJ, Zhang X (2007). Forestry. In "Climate Change 2007: Mitigation. Contribution of Working Group III to the Fourth Assessment Report of the Intergovernmental Panel on Climate Change" (Metz B, Davidson OR, Bosch PR, Dave R, Meyer LA eds). Cambridge University Press, Cambridge, United Kingdom and New York. NY, USA, pp. 584 .

Noormets A, Chen J, Crow TR (2007). Age-dependent changes in ecosystem carbon fluxes in managed forests in northern Wisconsin, USA. Ecosystems 10: 187-203. - doi: 10.1007/s10021007-9018-y

Noormets A, McNulty SG, Domec JC, Gavazzi M, Sun G, King JS (2012). The role of harvest residue in rotation cycle carbon balance in loblolly pine plantations. Respiration partitioning approach. Global Change Biology 18 (10): 3186-3201. - doi: 10.1111/j.1365-2486.2012.02776.x Nosetto MD, Jobbágy $E G$, Brizuela $A B$, Jackson $R B$ (2012). The hydrological consequences of land cover change in central Argentina. Agriculture, Ecosystems and Environment 154: 2-11. doi: 10.1016/j.agee.2011.01.008
Paul KI, Polglase PJ, Nyakuengama JG, Khanna PK (2002). Change in soil carbon following afforestation. Forest Ecology and Management 168: 241-257. - doi: 10.1016/S0378-1127(01)00740$X$

Paul KI, Polglase PJ, Richards GP (2003). Predicted change in soil carbon following afforestation or reforestation, and analysis of controlling factors by linking a $\mathrm{C}$ accounting model (CAMFor) to models of forest growth (3PG), litter decomposition (GENDEC) and soil $C$ turnover (RothC). Forest Ecology and Management 177 (1-3): 485-501. - doi: 10.1016/S03781127(02)00454-1

Peichl M, Arain MA, Ullah S, Moore TR (2010). Carbon dioxide, methane, and nitrous oxide exchanges in an age-sequence of temperate pine forests. Global Change Biology 16: 21982212. - doi: 10.1111/j.1365-2486.2009.02066.x

Reichstein M, Falge E, Baldocchi D, Papale D, Valentini R, Aubinet $M$, Berbigier $P$, Bernhofer C, Buchmann N, Gilmanov T, Granier A, Grünwald T, Havránková K, Janous D, Knohl A, Laurela $\mathrm{T}$, Lohila $\mathrm{A}$, Loustau $\mathrm{D}$, Matteucci $\mathrm{G}$, Meyers T, Miglietta F, Ourcival J-M, Rambal S, Rotemberg E, Sanz M, Tenhunen J, Seufert G, Vaccari F, Vesala T, Yakir D (2005). On the separation of net ecosystem exchange into assimilation and ecosystem respiration: review and improved algorithm. Global Change Biology 11: 1424-1439. - doi: 10.1111/j.1365-2486.2005.001002.x

Sabine CL, Feely RA, Gruber N, Key RM, Lee K, Bullister JL, Wanninkhof R, Wong CS, Wallace DW, Tilbrook B, Millero FJ, Peng TH, Kozyr A, Ono T, Rios AF (2004). The oceanic sink for anthropogenic CO2. Science 305 (5682): 367-371. doi: $10.1126 /$ science.1097403

Schmid HP (1994). Source areas for scalars and scalar fluxes. Boundary-Layer Meteorology 67: 293-318. - doi: 10.1007/BFo0713146 Schotanus P, Nieuwstadt FTM, De Bruin HAR
(1983). Temperature measurement with a sonic anemometer and its application to heat and moisture fluxes. Boundary-Layer Meteorology 26: 81-93. - doi: 10.1007/BF00164332

Shvidenko A, Nilsson S, Roshkov V (1997). Possibilities for increased carbon sequestration through the implementation of rational forest management in Russia. Water Air and Soil Pollution 94: 137-162. - doi: 10.1007/BF02407099 Strengers BJ, Müller C, Schaeffer M, Haarsma RJ, Severijns C, Gerten D, Schaphoff S, Van Den Houdt R, Oostenrijk R (2010). Assessing $20^{\text {th }}$ century climate-vegetation feedbacks of landuse change and natural vegetation dynamics in a fully coupled vegetation-climate model. International Journal of Climatology 30: 2055-2065. doi: 10.1002/joc.2132

Toland DE, Zak DR (1994). Seasonal patterns of soil respiration in intact and clear-cut northern hardwood forest. Canadian Journal of Forest Research 24 (8): 1711-1716. - doi: 10.1139/x94-221 Voldoire A (2006). Quantifying the impact of future land-use changes against increases in GHG concentrations. Geophysical Research Letters 33: 1-4. L04701. - doi: 10.1029/2005GL0243 54

Webb EK, Pearman GI, Leuning R (1980). Correction of flux measurements for density effects due to heat and water vapour transfer. Quarterly Journal of the Royal Meteorological Society 106: 85-100. - doi: 10.1002/qj.49710644707

Wilczak JM, Oncley SP, Page SA (2001). Sonic anemometer tilt correction algorithms. Boundary-layer meteorology 99: 127-150. - doi: 10.1023/ A:1018966204465

Yanai RD, Currie WS, Goodale CL (2003). Soil carbon dynamics after forest harvest: an ecosystem paradigm reconsidered. Ecosystems 6: 197212. - doi: 10.1007/s10021-002-0206-5 